\title{
Evaluation of protective properties of acrylate varnishes used for conservation of historical metal artefacts
}

\section{Hodnocení ochranných vlastností akrylátových laků používaných pro konzervaci historických kovových předmětů}

\author{
Švadlena J., Stoulil J. \\ University of Chemistry and Technology Prague, Department of Metals and Corrosion Engineering \\ E-mail: jan.svadlena@vscht.cz
}

Acrylate varnishes are due to their suitable properties frequently used in restoration and preservation on variety of historical objects and materials. Common practice of their application involves using as an adhesive agents, consolidants and protective coatings. The purpose of protective coatings especially on metal artefacts is to reduce access of pollutants to the surface of the artefact. In this paper, coatings prepared from two acrylate polymers Paraloid B72 and Paraloid B $48 \mathrm{~N}$ are compared in terms of permeability for water and level of protective properties against air pollutants. For this purpose, electrochemical impedance spectroscopy and resistometric method were chosen for analysis of the coatings. Obtained results show lower permeability for water in case of Paraloid B72. However, same coating provided lower protection against air pollutants than Paraloid B $48 N$ coating.

\section{INTRODUCTION}

Acrylate polymers are formed by polymerization of acrylic a methacrylic acid, preferably in the form of esters and other derivatives [1]. The resulting properties of acrylate polymers are determined by the structure of default monomers - monomers with branched-chained alcohol structure create harder polymers compared to monomers with straight-chained alcohol structure. In terms of glass transition temperature $T_{g}\left[{ }^{\circ} \mathrm{C}\right]$, polyacrylates have lower $T_{g}$ than polymethacrylates [2]. Acrylate polymers are widely applied in practice because of their suitable properties - reversibility, transparency, hydrophobicity [1], long-term stability, easy applicability and renewability of polymer layer, adhesion to the substrate and modifiability [3-5]. They can be used as protective coatings, adhesives and consolidants. Two methods of applications are possible: dissolved in organic solvent or as aqueous dispersion [1]. Acrylate polymers are suitable for broad range of historical materials including metals [3], stone and other interior
Akrylátové povlaky jsou vzhledem ke svým přihodným vlastnostem často použivány pro restaurováni a konzervaci různých historických predmètů a materiálů. V běžné praxi nacházeji uplatnění jako adheziva, konsolidanty nebo ochranné povlaky. Úkolem ochranných povlaki̊, předevšim pro historické kovové predměty, je omezeni prístupu polutantì $k$ povrchu chráněného materiálu. V této práci jsou porovnávány dva akrylátové polymery - Paraloid B72 a Paraloid B $48 N-z$ hlediska jejich permeability pro vodu a úrovni ochrany proti nejběžnějším vzdušným polutantům. Pro analýzu těchto povlakủ byly zvoleny metody elektrochemické impedančni spektroskopie a rezistometrie. Výsledky ukazuji nižši úroveň permeability pro vodu v prripadè Paraloidu B72, naopak lepši ochranu proti plynným polutantům poskytoval Paraloid B48N.

and exterior building materials $[4,6]$, murals $[1,7]$, glass and mosaic, ceramics, pigments and organic materials like paper or wood [8].

One of the acrylate copolymers frequently used in restoration and preservation of cultural heritage is Paraloid B72 composed of methyl acrylate/ethyl methacrylate $[2,5]$. Paraloid B72 is nowadays successfully used for treatment of both organic and inorganic materials, in the case of historical metal artifacts it serves as a finishing protective layer. As required during the treatment, Paraloid B72 can be applied on archeological objects with a layer of corrosion products as well as on clean metal surface $[1,3,7]$.

An alternative specifically designed for metallic materials is acrylate copolymer butyl methacrylate/ methyl methacrylate with commercial name Paraloid B48N [2, 5]. In comparison with the Paraloid B72 it provides harder coating (based on the structure with methacrylate monomers) with higher adhesion to the metal surface [9]. Basic properties of Paraloid B72 and B48N are compared in Table $1[10,11]$. 
Tab. 1. Basic properties of Paraloid B72 and Paraloid B48N / Základní vlastnosti Paraloidu B72 a Paraloidu B48N

\begin{tabular}{|c|c|c|c|c|}
\hline & Composition & $\boldsymbol{T}_{g}\left[{ }^{\circ} \mathbf{C}\right]$ & $\boldsymbol{M}_{w}\left[\mathbf{g} \mathbf{~ m o l}^{-1} \mathbf{]}\right.$ & $\boldsymbol{\rho}\left[\mathbf{g} \mathbf{~ c m}^{-3}\right]$ \\
\hline Paraloid B72 & methyl acrylate/ethyl methacrylate & 40 & 88 & 1.15 \\
\hline Paraloid B48N & butyl methacrylate/methyl methacrylate & 50 & 184 & 1.15 \\
\hline
\end{tabular}

$T_{g}$ - glass transition temperature; $M_{w}$-weight-average molar mass; $\rho$-density.

Protective effects of polymeric coating on historical metal artifacts consist in limiting access of water and other contaminants to the surface of the object. The ability of the coating to allow liquids and gases to pass through the layer (permeation) to the metal surface is described by permeability of the coating. Permeability is given by the equation (1):

$$
P=D \times S
$$

where $D\left[\mathrm{~m}^{2} \mathrm{~s}^{-1}\right]$ is diffusion coefficient of chemical substance (in the form of molecules) through the coating and $S[\%]$ is sorption of chemical substance (water, pollutants) into the coating. Permeability of polymeric coating is determined by chemical structure of the polymer, degree of crystallinity, temperature, presence of the additives or impurities and amount of stress in the coating [12].

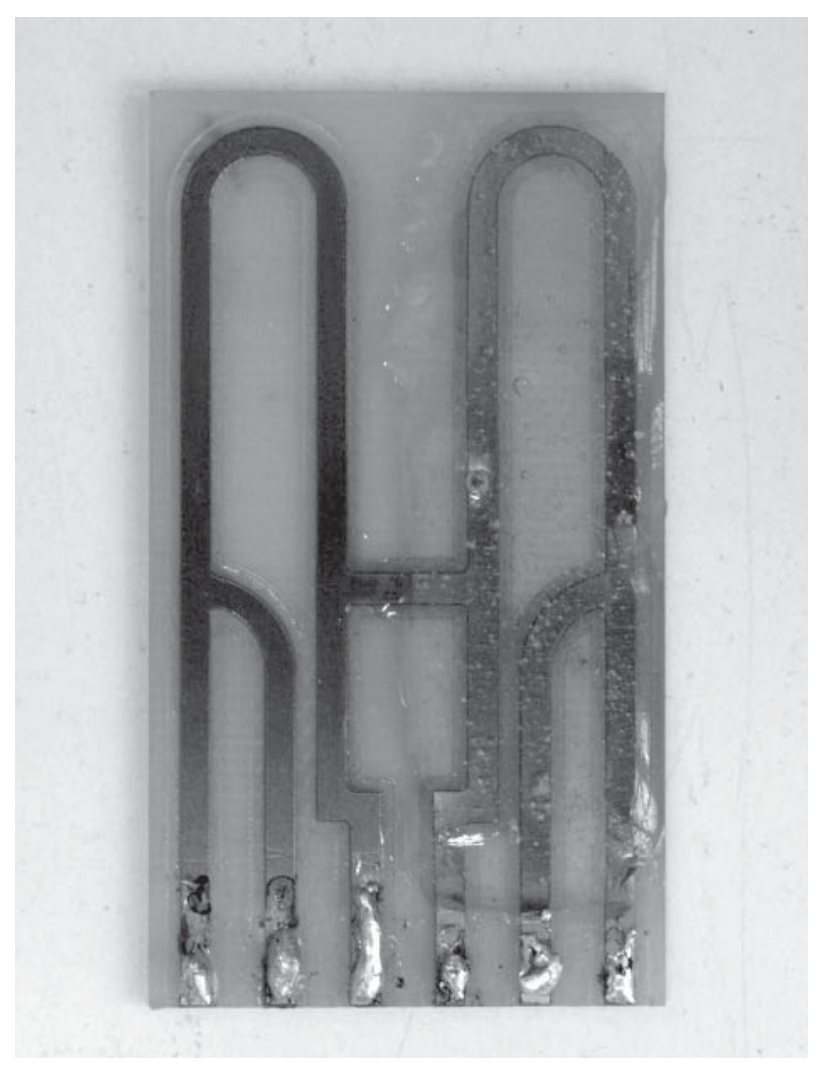

Fig. 1. Fe sensor for resistometric measurements. Reference part of the sensor (on the right) is covered with epoxy resin

Obr. 1. Železný resistometrický senzor. Referenční část senzoru (vpravo) je chráněna epoxydovou pryskyřicí
Evaluation of protective properties of the coating via permeability is mainly used for water, following the amount of water absorbed in the coating [13-15]. Gravimetry is common method to assess the amount of water in the coating and under specific condition it can be also used to determine the diffusion coefficient. Main drawback of gravimetry is its limitation for thick coatings only. Alternatively, infrared spectroscopy is applicable for water assessment in the coating due to absorption bands of hydroxyl groups -OH. This method is limited to very thin coatings [13].

For evaluation of water permeability in coating layer on conductive material, electrochemical impedance spectroscopy (EIS) as one of the advanced electrochemical methods can be used. Possibility of EIS applications for study of permeability is based on description of the coating as a plate capacitor. Presence of water in the coating alters its capacitance. Thus, diffusion coefficient and water sorption can be determined according to the change of the coating capacitance. Furthermore, EIS is not limited by the thickness of the coating, only limitation is porosity (coating should not be too porous) [13].

Evaluation of water content in the coating (water sorption) is based on mathematical models that consider different water distribution and levels of interaction of water with the coating. Correctness of these models is evaluated by comparing with the gravimetric method, which determines the amount of water in the coating directly. Frequently used model is Brasher - Kingsbury equation (4). Another model is presented by Castela \& Simòes [15], in which polymer coating is described as a combination of three insoluble phases (water, air and polymer).

EIS measurement allows, in addition to evaluation of water sorption, determination of the diffusion coefficient of water in the coating. The diffusion coefficient can be determined from the time dependence of capacitance change due to water absorption of the coating [16].

The effectiveness of the coating in a certain environment is normally monitored using different exposure tests that assess the degree of blistering or scratch and cut edge corrosion (according to EN ISO 4628). Resistometric method among other exposure tests provides great advantage in the possibility to monitor corrosive effect of the environment on the exposed sample in real time with continuous and quantitative evaluation of corrosion rate of the metal material under the intact 
coating. The principle of the method is based on increase of the resistance due to the loss of effective thickness on the cross-section of the metal track of the sensor (Fig. 1). From the corrosion loss versus time, actual corrosion rate of tested material under given conditions can be determined. This can be used for verifying of the influence of environmental changes on the material as well as for assessing the efficiency of the protective coating [17-20].

The objective of the research was to compare two acrylate copolymers (Paraloid B72 and Paraloid B48N) in terms of their ability to protect historical metal materials. Those acrylate copolymers are widely used in conservation for their suitable properties such as reversibility. Protective properties of prepared acrylate coatings were studied with use of electrochemical methods.

\section{MATERIALS AND METHODS}

\section{Specimens}

The acrylate coatings (applies to all types of samples) were prepared by dip-coating (each sample was immersed in the coating solution for 10 seconds in case of the first layer and 1 second for the second and the third layer). Each layer of the coating was left to cure properly at ambient conditions for 24 hours before another layer was applied. Samples with coating were than left additional 7 days at ambient conditions before measurements.

Triple-layer coatings of acrylate copolymers Paraloid B72 and Paraloid B48N (both as 10 wt. \% solution in acetone) were prepared on degreased and polished copper substrate (plates $5 \times 5 \mathrm{~cm}$ ) in order to evaluate water permeability in acrylate coatings using EIS. Same triple-layer coatings were prepared on copper (thickness of the metal track $18 \mu \mathrm{m}$ ) and iron (thickness of the metal track $100 \mu \mathrm{m}$, Fig. 1) sensors for resistometric method. Iron sensors were used for the determination of the diffusion coefficient. Before application of the coating, the measuring part of iron resistometric sensors was sensitized with $\mathrm{NaCl}$ solution in methanol for increase of corrosion rate after the water permeating through the coating reach to the surface of the sensor. Surface contamination of the sensors with chlorides was about $0,2 \mathrm{~g} \mathrm{~m}^{-2}$. Copper sensors (non-sensitized) were used for comparison of protective properties of the coatings against air pollutants. Reference part of the sensors, which serves as a compensation of the influence of varying temperature, was covered with thick layer ( $1 \mathrm{~mm}$ ) of epoxy resins. Resistometric sensors without acrylate varnish were used for comparison.

Weight gain and thickness of the layers were monitored during the preparation. For thickness measurement was part of the coating removed with acetone and height profile was measured using profilometer Mitutoyo SJ-301.

\section{Electrochemical impedance spectroscopy}

Single frequency EIS method was chosen for determination of diffusion coefficient and water sorption into the coating. In order to choose appropriate frequency for the experiment, preliminary tests were conducted - potentiostatic EIS measurement of the saturated coating with the frequency range $100 \mathrm{kHz}-10 \mathrm{mHz}$ (at open circuit potential). Acquired EIS spectra (Fig. 2) were modeled using equivalent circuit (Fig. 3) with two constant-phase elements (CPE).

Based on preliminary tests, frequency $10 \mathrm{kHz}$ was chosen for experiment because of capacitive behavior of prepared coatings. Specimen (copper plate with triplelayer acrylate coating) was placed in the cell with two electrode arrangement including $\mathrm{Pt}$ counter-electrode with large surface $\left(2 \mathrm{~cm}^{2}\right)$. Shortly before start of the

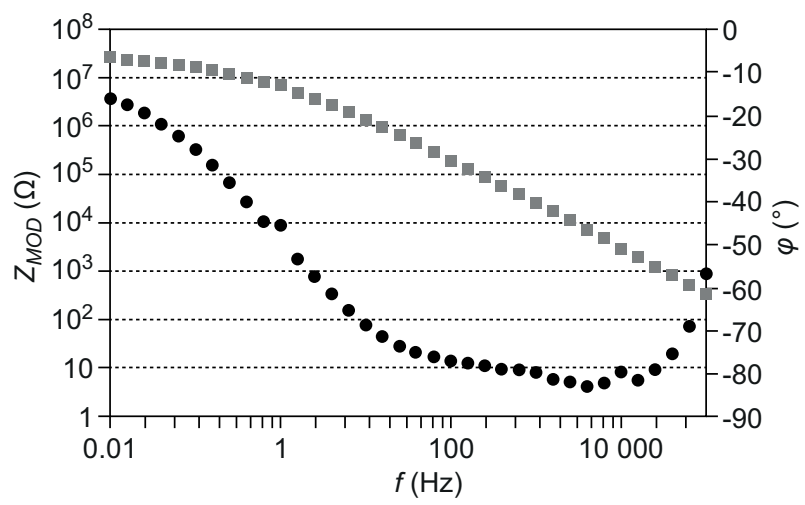

Fig. 2. Example of acquired EIS spectrum (Bode plot) with impedance modulus $Z_{\text {MOD }}$ (square data points) and phase angle $\varphi$ (circle data points)

Obr. 2. Ukázka naměřeného EIS spektra (Bodeho zobrazení) $s$ modulem impedance $Z_{M O D}$ (čtvercové body) a fázovým posuvem $\varphi$ (kruhové body)

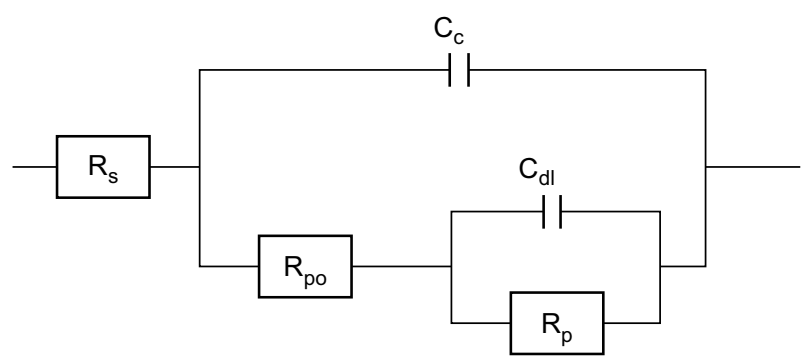

Fig. 3. Equivalent circuit for EIS data analysis. $R_{s}$ represents resistance of the electrolyte, $R_{p o}$ represents resistance of the electrolyte in pores, $\mathrm{C}_{c}$ represents capacity of the coating, $C_{d l}$ represents double layer capacity and $R_{p}$ represents charge transfer resistance.

Obr. 3. Ekvivalentní obvod pro analýzu EIS dat. Rs představuje odpor elektrolytu, $R_{p o}$ predstavuje odpor elektrolytu $v$ pórech, $C_{c}$ představuje kapacitu povlaku, $C_{d l}$ predstavuje kapacitu elektrické dvojvrstvy a $R_{p}$ predstavuje odpor proti prenosu náboje. 
measurement the cell with the sample was filled with electrolyte - artificial rain water (Table 2). Obtained data were converted as a dependence of coating saturation on the square root of time. Diffusion coefficient $D_{\text {water }}\left[\mathrm{m}^{2} \mathrm{~s}^{-1}\right]$ of water molecules through the coating was determined from the linear portion of the dependence using equations $(2,3)$

$$
\begin{gathered}
\frac{C_{t}-C_{0}}{C_{S A T}-C_{0}}=k t^{\frac{1}{2}} \\
\left(\frac{k L}{4}\right)^{2} \cdot \pi=D_{\text {water }}
\end{gathered}
$$

where $C_{t}$ is coating capacity at time $t, C_{0}$ is coating capacity at time $t=0, C_{S A T}$ is capacity of saturated coating, $k$ is slope of linear portion of the dependence and $L$ is thickness of the coating [21].

The sorption of water $S_{\text {water }}[\%]$ was determined using Brasher - Kingsbury model (4) with $\varepsilon_{w}$ as the dielectric constant of water

$$
S_{\text {water }}=100 \cdot \frac{\log \frac{C_{S A T}}{C_{0}}}{\log \varepsilon_{w}}
$$

\begin{tabular}{|c|c|}
\hline & Content $\left[\mathrm{mg} \mathrm{dm}^{-3}\right]$ \\
\hline $\mathrm{Na}_{2} \mathrm{SO}_{4}$ & 852 \\
\hline $\mathrm{MgCl}_{2}$ & 4.3 \\
\hline $\mathrm{CaCl}_{2}$ & 3.1 \\
\hline $\mathrm{NaCl}$ & 8.9 \\
\hline $\mathrm{NH}_{4} \mathrm{NO}_{3}$ & 10.5 \\
\hline
\end{tabular}

Tab. 2. Composition of artificial rainwater (electrolyte) / Složeni umělé deštové vody (elektrolyt)

\section{Resistometric method}

Increase of resistance due to the loss of thickness of the measuring part of the sensor in time was monitored for the determination of the diffusion coefficient. Experiment was carried out at temperature $25{ }^{\circ} \mathrm{C}$ and $100 \%$ relative humidity (RH). Diffusion coefficient was assessed from the time at which molecules of water permeated through the coating to the surface and caused increase of the corrosion rate. Relation between increase of the resistance and loss of thickness of the metal track $\Delta d[\mu \mathrm{m}]$ is described by the equation (5)

$$
\Delta d=d_{\text {init }}\left(1-\frac{R_{\text {ref }}}{R_{\text {sens }}} \frac{R_{\text {sens, init }}}{R_{\text {ref,init }}}\right)
$$

where $d_{\text {init }}$ represents initial thickens of the metal track of the sensor, $R_{\text {ref }}$ represents resistance of the reference part of the sensor, $R_{\text {sens }}$ represents resistance of the measuring part of the sensor, $R_{\text {sens,init }}$ and $R_{\text {refinit }}$ represent initial resistances of the parts of the sensor [16]. Diffusion coefficient $D_{\text {vapour }}\left[\mathrm{m}^{2} \cdot \mathrm{s}^{-1}\right]$ can be than determined as

$$
D_{\text {vapour }}=\frac{L^{2}}{2 t}
$$

where $L$ is thickness of the coating and $t$ time from the start of the measurement in $100 \% \mathrm{RH}$ to change of the slope in the corrosion loss vs. time dependence (it is equal to the time when the first molecules of water permeate to coating - metal interface). Additionally, corrosion rate of the iron beneath the coating were determined.

\section{Comparison of protective properties against pollutants (resistometric method)}

Throughout the measurement temperature was maintained at $25{ }^{\circ} \mathrm{C}$. Initially, copper resistometric sensors were tempered for 1 hour then the relative humidity was increased to $100 \%$ and after 4 hours selected pollutant was added to the atmosphere. Pollutants were prepared in the form of diluted or saturated solutions, which were placed with the samples in a sealed container $\left(\right.$ c. $\left.8 \mathrm{dm}^{3}\right)$ :

- conc. $\mathrm{NH}_{3}$ (25 wt. \%),

- conc. $\mathrm{CH}_{3} \mathrm{COOH}$ (96 wt. \%),

- saturated solution of $\mathrm{Na}_{2} \mathrm{~S}$, acidified with conc. $\mathrm{H}_{2} \mathrm{SO}_{4}$,

- diluted solution of $\mathrm{Na}_{2} \mathrm{SO}_{3}$ (1 wt. \%) acidified with conc. $\mathrm{H}_{2} \mathrm{SO}_{4}$,

In all cases, concentration of pollutant was by 6 orders of magnitude higher than is usual in polluted atmospheres. The reason was to clearly distinguish the change of the corrosion rate from the measurement error.

Determination of diffusion coefficient for pollutants with resistometric method was not possible - the method did not provide sufficient sensitivity to record any delay between adding selected pollutant to the atmosphere

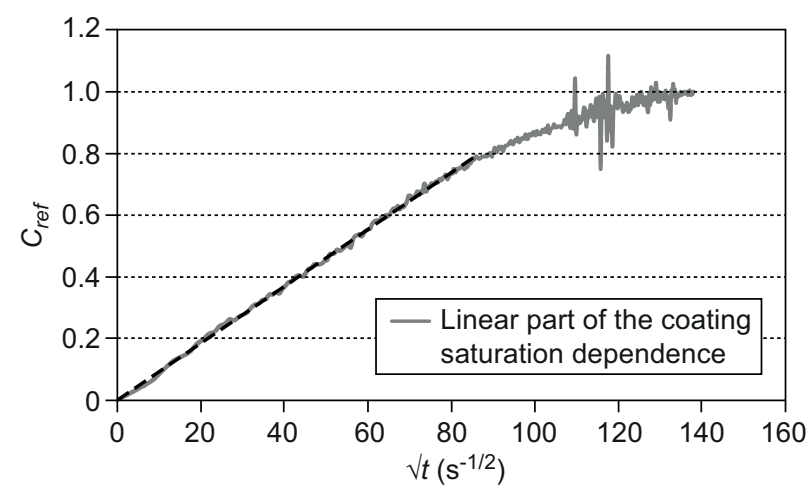

Fig. 4. Linear part of dependence of the coating saturation on square root of time (EIS measurement)

Obr. 4. Lineární část závislosti nasycení povlaku na čase (EIS měření) 
and increasing of the corrosion rate, regardless of the concentration. For this reason the protective properties of both coatings were compared in terms of decrease of the corrosion rate.

\section{RESULTS}

Thickness of both triple-layered coatings prepared by immersion in $10 \mathrm{wt}$ \% solution of acrylate copolymer in acetone was $7 \mu \mathrm{m}$. Thickness was calculated from the weight gain and was confirmed by measurement with profilometer.

\section{Electrochemical impedance spectroscopy}

$C_{t}, C_{0}$ and $C_{S A T}$ (equation (2)) values were obtained from the time dependence of the coating capacity (EIS data from the single frequency measurements). Figure 4 shows linear part of dependence of the coating saturation ( $C_{r e l}$, left part of the equation (2)) on square root of time which was used to determine the diffusion coefficient. Obtained values equipped with a standard deviation $\sigma$ (4 samples of each coating were used) are summarized in Table 3. $D_{\text {water }}$ values are based on the direct contact of the coating with water. $D_{\text {vapour }}$ values, on the other hand, correspond to molecules that diffuse through the coating from the environment of saturated water vapour. To calculate $D_{\text {water }}$ is thus available complete dependence of the coating saturation while in the case of $D_{\text {vapour }}$ there are only two points of the dependence available - the beginning (correspond to an increase of humidity) and time when first molecules of water permeate through the coating to the substrate. Therefore, accuracy of the value $D_{\text {water }}$ (EIS method) is higher than the values from $D_{\text {vapour }}$ resistometric method. This inaccuracy explains the fact that $D_{\text {vapour }}>D_{\text {water }}$, which would mean a higher diffusion rate from the vapour phase compared to liquid phase that does not reflect the reality because water molecules in liquid phase have higher activity than in vapour phase. Paraloid B72 evinced the lowest permeability for water (i.e. low diffusion coefficient and water sorption into the coating). Lower permeability of Paraloid B72 compared to Paraloid B48N was also confirmed by corrosion rates (measured with iron resistometric sensors, Table 3). Higher permeability of Paraloid B48N indicates that despite the expected higher interconnection of molecules has Paraloid B48N probably higher interparticle distance of molecules (density of both polymers is identical, see Table 1). Also in terms of the water sorption into the coating Paraloid B72 showed lower values which further confirm the results of impedance measurement.

\section{Resistometric method}

Interval between increase of $\mathrm{RH}$ to $100 \%$ and growth of the corrosion rate during $D_{\text {vapour }}$ measurement using resistometric method is shown in the Figure 5 (first vertical line indicates increase of relative humidity, second line indicates change of the slope due to the growth of the corrosion rate). This interval corresponds to the diffusion of water through the acrylate coating. Results are shown in the Table 3 together with the $D_{\text {water }}$ results from EIS measurement with comparison mentioned before. Paraloid B72 achieved lower diffusion coefficient $D_{\text {vapour }}$ as before in the case of $D_{\text {water }}$.

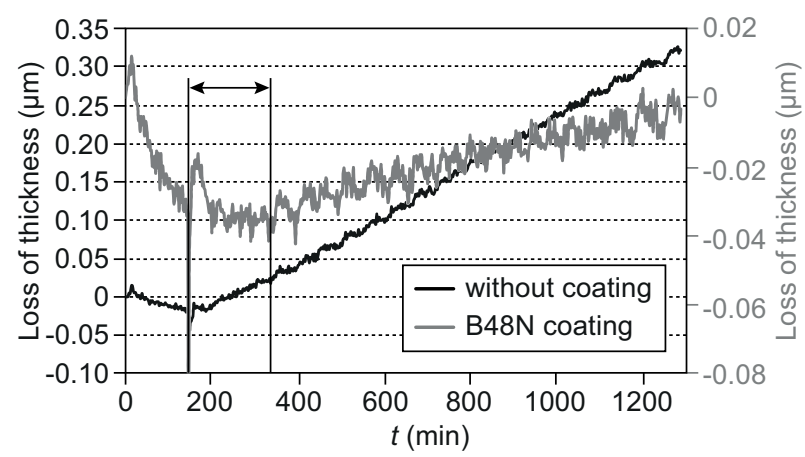

Fig. 5. Evaluation of diffusion coefficient through increase of corrosion rate (the highlighted interval corresponds to the diffusion of water through the acrylate coating)

Obr. 5. Vyhodnocení difúzního koeficientu prostrednictvím nárůstu korozní rychlosti (zvýrazněný interval odpovídá difúzi vody povlakem)

\section{Comparison of protective properties against pollutants (resistometric method)}

Table 4 presents results numerical values of the corrosion rates and Figure 6 compares the decrease of corrosion rates caused by the presence of the acrylate coating (contrary to the samples without coating). Both copolymers have similar protective properties in an environment of sulfur dioxide, hydrogen sulfide and vapours of acetic acid.

Tab. 3. Comparison of water sorption $S_{\text {water }}$, corrosion rates $v_{\text {corr }}$ and diffusion coefficients $D$ for water in tested coatings / Porovnáni koroznich rychlostí $v_{\text {corr }}$ rozpustnosti $S_{\text {water }}$ a difúznich koeficientů D pro vodu v testovaných povlacích

\begin{tabular}{|l|c|c|c|c|}
\hline & $\mathbf{S}_{\text {water }}[\mathbf{\%}]$ & $\mathbf{D}_{\text {water }}\left[\mathbf{m}^{2} \mathbf{s}^{-1}\right]$ & $\mathbf{D}_{\text {vapour }}\left[\mathbf{m}^{2} \mathbf{s}^{-1}\right]$ & $\mathbf{v}_{\text {corr }}\left[\boldsymbol{\mu m} \mathbf{a}^{-1}\right]$ \\
\hline Paraloid B72 & $1.0 \pm 0.0$ & $1.0 \mathrm{E}-15 \pm 0.4 \mathrm{E}-15$ & $3.4 \mathrm{E}-15 \pm 0.2 \mathrm{E}-15$ & 6.8 \\
\hline Paraloid B48N & $1.5 \pm 0.0$ & $3.6 \mathrm{E}-15 \pm 1.0 \mathrm{E}-15$ & $4.2 \mathrm{E}-15 \pm 1.3 \mathrm{E}-15$ & 15.7 \\
\hline
\end{tabular}


Tab. 4. Comparison of corrosion rates in pollutants / Porovnáni korozních rychlostí v prostredi polutantů

\begin{tabular}{|l|c|c|c|c|c|}
\hline \multirow{2}{*}{} & \multicolumn{5}{|c|}{ Corrosion rates in chosen pollutants $\left[\boldsymbol{\mu m} \mathbf{.}^{-1}\right.$ ] } \\
\cline { 2 - 6 } & $\mathbf{H}_{\mathbf{2}} \mathbf{O}$ & $\mathbf{S O}_{\mathbf{2}}$ & $\mathbf{H}_{\mathbf{2}} \mathbf{S}$ & $\mathbf{C H}_{\mathbf{3}} \mathbf{C O O H}$ & $\mathbf{N H}_{\mathbf{3}}$ \\
\hline without coating & $157.5 \pm 0.5$ & $23.7 \pm 3.7$ & $157.5 \pm 74.2$ & $29.0 \pm 4.2$ & $184.0 \pm 111.7$ \\
\hline Paraloid B72 & $6.8 \pm 5.1$ & $0.8 \pm 0.4$ & $0.4 \pm 0.1$ & $4.2 \pm 0.0$ & $45.0 \pm 11.3$ \\
\hline Paraloid B48N & $15.7 \pm 0.0$ & $0.5 \pm 0.0$ & $0.7 \pm 0.5$ & $3.2 \pm 0.1$ & $53.0 \pm 0.0$ \\
\hline
\end{tabular}

More noticeable difference stems from the results for ammonia environment in which Paraloid B48N shows better performance. On the contrary, Paraloid B72 shows slightly better protection against water.

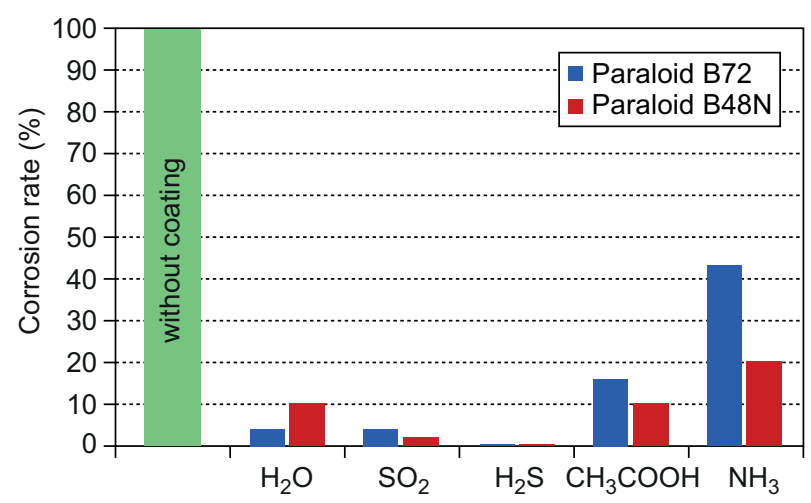

Fig. 6. Protective effect of the coatings against various pollutants (comparison through the decrease of the corrosion rate)

Obr. 6. Ochranné působení povlaku proti různým polutantům (porovnání prostřednictvím snížení korozní rychlosti)

\section{CONCLUSIONS}

Using electrochemical impedance spectroscopy and resistometric method it was possible to evaluate permeability of water in two organic coatings of acrylate polymers Paraloid B72 and Paraloid B48N. The comparison shows lower permeability and therefore better protective properties against water for Paraloid B72.

Protective performance of the coatings against pollutants was evaluated by comparing of the corrosion rates of the substrate with resistometric measurements. The greatest difference between the two coatings was in the case of environment with ammonia - Paraloid B48N had significantly better protective properties. Also, in the environment with acetic acid fared better Paraloid B48N. Confirmation of previous results for water permeability is lower corrosion rate of Paraloid B72.

\section{Acknowledgment}

Financial Support from Specific University Research (MSMT No. 20/2013).

\section{REFERENCES}

1. Carretti, E. \& Dei, L. Physicochemical characterization of acrylic polymeric resins coating porous materials of artistic interest. Progress in Organic Coatings 2004, 49, 282-289.

2. Kotlik, P., Doubravova, K., Horalek, J., Kubac, L. \& Akrman, J. Acrylic copolymer coatings for protection against UV rays. Journal of Cultural Heritage 2014, 15 (1), 44-48.

3. Cano, E., Bastidas, D.M., Argyropoulos, V., Fajardo, S., Siatou, A., Bastidas, J.M., \& Degrigny, C. Electrochemical characterization of organic coatings for protection of historic steel artefacts. Journal of Solid State Electrochemistry 2010, 14(3), 453-463.

4. Kapolos, J., Bakaoukas, N., Koliadima, A. \& Karaiskakis, G. Evaluation of acrylic polymeric resin and small siloxane molecule for protecting cultural heritage monuments against sulfur dioxide corrosion. Progress in Organic Coatings 2007, 59(2), 152-159.

5. Chiantore, O. and Lazzari, M. Characterization of Acrylic Resins. International Journal of Polymer Analysis and Characterization 1996, 2(4), 395-408.

6. Castelvetro, V., Aglietto, M., Ciardelli, F., Chiantore, O., Lazzari, M. \& Toniolo, L. Structure Control, Coating Properties, And Durability of Fluorinated Acrylic-Based Polymers. Journal of Coatings Technology 2002, 74 (929), 57-66.

7. Miliani, C., Ombelli, M., Morresi, A. \& Romani, A. Spectroscopic study of acrylic resins in solid matrices. Surface and Coatings Technology 2002, 151, 276-280.

8. Chiantore, O. \& Lazzari, M. 2001. Photo-oxidative stability of paraloid acrylic protective polymers. Polymer 2001, 42(1), 17-27.

9. Stoulil, J., Kopecka, A. \& Fiserova, P. 2014. Adhesion of acrylate varnishes to historical metallic materials. Koroze a ochrana materialu 2014, 58(3), 71-74.

10. Rohm and Haas. 2007a. Paraloid B-72 Technical data sheet. [online] [accessed 12 April 2016]. Available at: http://www. dow.com/assets/attachments/business/pcm/paraloid_b/ paraloid_b-72_100_pct/tds/paraloid_b-72_100_pct.pdf

11. Rohm and Haas. 2007b. Paraloid B-48N Technical data sheet. [online] [accessed 12 April 2016]. Available at: http:// www.dow.com/assets/attachments/business/pcm/paraloid_ b/paraloid_b-48n_100_pct/tds/paraloid_b-48n_100_pct. pdf

12. Comyn, I. Polymer Permeability. London/New York: Elsevier Applied Science Publisher, 1985.

13. Philippe, L.V.S., Lyon, S.B., Sammon, C. \& Yarwood, J. 2008. Validation of electrochemical impedance measurements for water sorption into epoxy coatings using gravimetry and infra-red spectroscopy. Corrosion Science 2008, 50(3), 887-896. 
14. Duarte, R.G., Castela, A.S. \& Ferreira, M.G.S. 2009. A new model for estimation of water uptake of an organic coating by EIS: The tortuosity pore model. Progress in Organic Coatings 2009, 65(2), 197-205.

15. Castela, A.S. \& Simòes, A.M. 2003. Assessment of water uptake in coil coatings by capacitance measurements. Progress in Organic Coatings 2003, 46(1), 55-61.

16. Mansfeld, F. 2006. Electrochemical Impedance Spectroscopy. In: P. Marcus and F. Mansfeld, eds. Analytical methods in corrosion science and engineering, $1^{\text {st }}$ ed. Boca Raton: CRC Press, pp. 463-505.

17. Prosek, T., Le Bozec, N. \& Thierry, D. 2012. Application of automated corrosion sensors for monitoring the rate of corrosion during accelerated corrosion tests. Materials and Corrosion 2012, 63, 1-9.

18. Kouril, M., Prosek, T., Dubus, M., Taube, M., Hubert, V., Scheffel, B., Degres, Y., Jouannic, M. \& Thierry, D. 2012. Corrosion monitoring in the hands of restorers and conservators. Koroze a ochrana materialu 2012, 56(3), 67-75.

19. Prosek, T., Kouril, M., Hilbert, L.R., Degres, Y., Blazek, V., Thierry, D. \& Hansen, M.O. 2008. Real time corrosion monitoring in atmosphere using automated battery driven corrosion loggers. Corrosion Engineering, Science and Technology 2008, 43(2), 129-133.

20. Kouril, M., Prosek, T., Scheffel, B. \& Degres, Y. 2014. Corrosion monitoring in archives by the electrical resistance technique. Journal of Cultural Heritage 2014, 15(2), 99-103.

21. Moreno, C., Hernandez, S., Santana, J.J., Gonzales-Guzman, J., Souto, R.M. \& Gonzales, S. 2012. Characterization of Water Uptake by Organic Coatings Used for the Corrosion Protection of Steel as Determined from Capacitance Measurements. International Journal of Electrochemical Science 2012, 7, 8444-8457. 